\title{
Project Activities of the Chair for Digital Humanities and Modern Trends in the Development of Information Technology
}

\author{
Maksim V. Rumyantsev and Ivan N. Rudov* \\ Siberian Federal University \\ 79 Svobodny, Krasnoyarsk, 660041, Russia
}

Received 20.02.2016, received in revised form 23.03.2016, accepted 15.05.2016

The article discusses the results of the project activities of the Chair for Information Technology in Creative and Cultural Industries of the School for epy Humanities, Siberian Federal University, in the aspect of information technology changes.

Keywords: augmented reality, 3D modelling, virtual reconstruction, museum, digitalization, historical and cultural heritage, project management.

DOI: 10.17516/1997-1370-2016-9-7-1668-1673.

Research area: culture studies.

\section{Review of projects and technologies}

(2007-2015)

Since 2006, the Chair for Information Technology in Creative and Cultural Industries has been running an undergraduate programme, and since 2012 a postgraduate programme in "Applied Computer Science in Arts and the Humanities".

The success of the projects implemented by the academic staff and students of the Chair was determined by three circumstances:

1) interaction of the academic staff members (specialists in various fields of science: philosophers, historians, art historians and computer scientists) in educational and project activities;

2) interdisciplinary nature of the educational programme: combination of classical subjects of the humanities (History of Arts, History of Museums. Museums of the World, History of Material Culture and Everyday Life, etc.) and subjects of the professional field of knowledge (Information Technology in Museum Work, 3D Modelling Technology, Development and Processing of Digital Video and Audio, etc.);

3) possibility to organize project work of students by including the courses into the educational programme, which aim at development of project management skills: Introduction into Project Management, Project Practice; Multimedia Project Management.

The first major result in development of the complete digital project relates to 2007 and is associated with the development of the multimedia programme "Museum-Estate of Vasily Surikov

(c) Siberian Federal University. All rights reserved

* Corresponding author E-mail address: rudov.ivan@gmail.com 
in Krasnoyarsk. Excursion. Catalogue. Gallery" (http://tube.sfu-kras.ru/video/374). The object for computerization had become the memorial museum of Krasnoyarsk: the family house of the outstanding Russian artist Vasily Surikov (18481916). The authenticity of the Siberian Cossack homestead recreated in the museum; unique collection of works and personal belongings of the artist; the great documentary archive had defined the concept of the project, as indicated in its name. The resource includes an interactive video tour, the collection catalogue, the gallery of family photos.

Another typical detail connected with the history of this project and that has become an important element of the project work in general is fundraising. It allows to attract additional resources and do the job professionally. Almost all of the projects presented in this article have been supported by various grant organizations ${ }^{1}$.

The first experience has determined the main trends for the project activities of the Chair for the last ten years: the search of optimal approaches to digitalization of the museum collections and ergonomic solutions on their presentation.

The successive two years are connected with testing of the given principles and creation of digital resources on CD-ROMs: Digital Encyclopedia "Ethnic Groups of Siberia” (http:// tube.sfu-kras.ru/video/373); multimedia resource "Surikov and His Epoch" (http://tube.sfu-kras.ru/ video/375); electronic guide on Krasnoyarsk Art Museum of V.I. Surikov (http://tube.sfu-kras.ru/ video/376), etc.

In2009, it was decided to stop the development of digital resources on local careers and continue with the network ones. The first major Internet project was the creation of web-representation of the largest Museum of Fine Arts in the Asian part of Russia - Krasnoyarsk Art Museum of V.I. Surikov (http://www.surikov-museum.ru/). The museum's collection is represented by ancient
Russian art (icons, including Siberian icons, brass castings, church utensils); Russian art of the $18^{\text {th }}-$ beginning of the $20^{\text {th }}$ centuries. (I.E. Repin, I.K Aivazovsky, V.A. Tropinin, A.P. Bogolyubov, I.I. Shishkin, V.I. Surikov, etc.); the art of the $20^{\text {th }}$ $-21^{\text {st }}$ centuries. (V.V. Kandinsky, K.S. Malevich, A.M. Rodchenko, L.S. Popova, I.E. Grabar, etc.); collection of decorative, applied and folk art.

The key objectives of the projects have become the presentation of the museum collection items in high resolution and quick access of the user to such digital content (http://www.surikovmuseum.ru/taxonomy/term/1).

Digitizing experience resulting from the implementation of the project allowed to apply the technique of professional photographic capture of fine art (paintings, drawings, sculptures, works of decorative and applied art), which was later repeatedly used in other projects: the electronic collection of the Geology Museum of Central Siberia (http://database.mgeocs.ru/); the regional art exhibition "Autumn Vernissage" (http://av2010.ru/); the interregional youth art exhibition "Young Siberia" (http://young-siberia.ru), etc.

The project of web-representation of Krasnoyarsk Art Museum of V.I. Surikov appears to be quite integral due to another common visualization technology: a virtual tour of the museum implemented on the basis of 3D panoramic photographs of the exhibition space (http://www.surikov-museum.ru/tour).

Later on, this technology had been successfully applied in other "non-museum" projects initiated by the Chair: a virtual tour of Siberian Federal University (http://vt.sfu-kras. ru/), a virtual tour of TakmakSpa Hotel (http:// vt.takmakhotel.ru/).

In2010, the staff of the Chair began solving another problem in the field of digital culture: searching for the way to present lost historical and cultural landmarks using three-dimensional modelling technology. The 
analysis of international experience showed that approaches to reconstruction of heritage sites in virtual environment are quite heterogeneous, characterizedbyattentioneithertohistoricaldetails or to the visual component of the projects. The design team tried to eliminate such contradictions by proposing the concept of development of an interactive virtual reconstruction of lost or partially lost landmarks, which offers historical authenticity, high quality of visualization and interactivity of the space (http://www.yeniseiskheritage.ru/3d-reconstructions/ru).

Lost Orthodox churches in Yeniseisk, the oldest town in Siberia, had become the object of $3 \mathrm{D}$ virtual reconstruction. The unique historical buildings of Yeniseisk are included in the UNESCO preliminary list.

The significance of the results, as well as the need for their methodical interpretation resulted in updating the course "3D Modeling Technology" of the educational programme, as well as the development of a new course "Virtual Reconstruction" (http://tube.sfu-kras. $\mathrm{ru} / \mathrm{video} / 836$ ).

Cooperation with the largest Russian museums - the State Russian Museum and the State Hermitage Museum - allowed to adapt and implement gigapanoramic photographic technology (http://gigapan.com/gigapans/87249). In 2010-2015 ultra-high resolution digital copies of large-scale works by prominent Russian painters appeared: "Parade Celebrating the End of Military Action in the Kingdom of Poland on Tsaritsa Meadow in St Petersburg on 6 October 1831" by Chernetsov; "The Cossacks Writing a Letter to the Turkish Sultan" by Repin; "The Capture of the Snow Town" by Surikov; digital copies of unique petroglyphs of Okunevskaya culture.

The study of the trends in the development of digital technology has revealed another current visualization technology: the technology of augmented reality (AR). Its use is associated with the development of multimedia projects recreating museum exhibits in the virtual environment. Thus, in 2014 the project "Augmented Reality: Petroglyphs of the Okunevskaya culture" contributed to the expansion of traditional features of the museum environment, creation of an attractive image of unique artifacts: stone sculptures and plates of the Okunevskaya culture and Scythian time that are in open storage of the Storage Facility of the State Hermitage.

\section{Visualization technologies in the world practice}

The given overview of projects and technologies that define their specific character, suggests that higher education pays attention to changes in the IT-sphere resulting in application of leading digital technology in the humanities, understanding of their meaning and impact on this area of expertise. It is significant that since 2005 more than 500 scientific papers on the issue of digitalization of museum content and landmarks of cultural significance have been published worldwide. Most of these publications are devoted to the issues similar to those discussed in the first part of this work.

For example, J. Pallud outlines that it is important for the museums to be present in the Internet, and a museum website should comply with the latest trends in web design and information technology. Due to the fact that museums provide services on leisure activities and preserve cultural values, they have to compete with websites of commercial companies (in tourism, sports and entertainment). The latter are interested in the user: fighting over them leads to improvement in their functionality, design and interactive elements. These factors should be considered in the development of museum websites, most of which tend to be focused 
primarily on functionality that is not always a suitable type design for today's Internet users.

An important role in the development of the museum resource plays studying the peculiarities of its construction and evaluation of its effectiveness. The museum website should give necessary information to the user and provide the tools for working with this information. It is that the museum website should become effective and best meet the needs of the modern user. Along with the obligatory presentation of the collection, another way to attract users to the website is a virtual tour of a museum or a virtual exhibition, content personalization (such as creating your own collection), social services, the possibility of downloading, etc.

S. Sylaiou's article presents the idea of creating virtual museum exhibitions based on web technologies and augmented reality systems. B. Hemminger, G. Bolas, D. Schiff describe a technique that is based on three-dimensional graphics and allows users to take a virtual tour of exhibition rooms of a museum.

An important role in digitization of cultural content plays the quality of digitization. For example, M. Ben-Ezra considers technical features of gigapanoramic shooting to digitize art objects requiring preservation. Such an approach to digitization of art produces a digital image in a very high resolution, while maintaining the smallest details of paintings.

Three-dimensional graphics allows to record and store in digital form not only single objects, but also the city's architectural complexes. Some publications devoted to this topic consider opportunities of 3D modelling for the preservation of monuments and sculptures, digital methods of fixing the dimensional models of archaeological collections. Particular attention is paid to the international archaeological community's access to digitization of materials. This approach is efficient in comparison with traditional methods of preserving archaeological collections, while its advantage is not only the access itself, but also the ability to recover lost pieces of artifacts in the digital environment. Researchers of Tomsk State University describe a high-precision methods of recording the archaeological excavation in the field. Such techniques allow not only to increase the level of objectivity of archaeological research, but also to disclose and update the historical heritage.

Finally, in our opinion, the search of researchers aimed at the use of advanced visualization technology has resulted in the world's largest projects related to the presentation of historical and cultural content: GoogleCulturalInstitute (GoogleArtProject) and Europeana.

\section{Conclusion}

Thus, the project activity of the Chair as described in the first part of this article, is related to the changes that appear in the culture of the last decade and which indicate similar studies. The application of the described imaging technology has been always preceded by its study related to solving the tasks that are adequate to the idea of cultural object representation: scientific, educational and enlightening. In this case, the digital technology becomes an important tool for learning about the world of culture, accurately and convincingly presenting its values for reference, study and research.

\footnotetext{
The development of the virtual tour in the museum-estate of V.I. Surikov in Krasnoyarsk (regional grant programme "Social Partnership for Development", 2007); the electronic encyclopedia "Ethnic Groups of Siberia" (Foundation for Cultural Initiatives "Prokhorov Foundation", 2008); the online reference system "Collections of Krasnoyarsk Art Museum of V.I. Surikov" (Krasnoyarsk Regional Fund for Supporting Research and Technology Activities, 2009); actualization of historical and cultural heritage (the Federal Target Programme "Research and Academic Staff of Innovative Russia" for 2009-2013, 2009-2011); the virtual historical reconstruction of the lost architectural monuments using three-dimensional
} 
modelling and visualization technologies in real-time (Russian Foundation for the Humanities, 2011); the online reference system "Collections of Geology Museum of Central Siberia" (Krasnoyarsk Regional Fund for Supporting Research and Technology Activities, 2012).

\section{References}

Abel, R.L., Parfitt, S. \& Ashton, N. (2011). Digital preservation and dissemination of ancient lithic technology with modern micro-CT, In Computers \& Graphics, (35), 878-884.

Baryshev, R.S., Rumyantsev, M.V., Rudov, I.N. \& Pikov, I.N. Metodologicheskie rekomendatsii po sozdaniiu virtual'nykh rekonstruktsii adaptirovannykh $\mathrm{k}$ tekhnologii vizualizatsii $\mathrm{v}$ real'nom vremeni [Methodological guidelines on development of virtual reconstructions adjusted to real-time visualization technology]. Avaiable at: http://www.yeniseisk-heritage.ru/evaluation_guidelines/ru.

Ben-Ezra, M. (2011). A digital gigapixel large-format tile-scan camera, In IEEE Computer Graphics and Applications, 1 (31), 49-61.

Di Bias, N. (2002). Evaluating the features of museum websites: (the Bologna Report), In Museums and the Web 2002: Proceedings, 1 (11), 31-36.

Europeana. Available at: http://www.europeana.eu/portal/

Giakoumis, I. (2006). Digital image processing techniques for the detection and removal of cracks in digitized paintings, IEEE Transactions on Image Processing, 1 (15), 178-188.

GoogleArtProject. - Available at: https://www.google.com/culturalinstitute/beta/u/0/project/artproject?hl=ru.

Hemminger, B.M. (2004). Capturing content for virtual museums New York. New York, USA: ACM Press, $379 \mathrm{p}$.

Ikeuchi, K. (2007). The Great Buddha Project: Digitally Archiving, Restoring, and Analyzing Cultural Heritage Objects, In International Journal of Computer Vision, 1 (75), 189-208.

Koutsoudis, A. (2007). On 3D reconstruction of the old city of Xanthi. A minimum budget approach to virtual touring based on photogrammetry, In Journal of Cultural Heritage, 1 (8), 26-31.

Lanitis, A. (2012). Virtual restoration of faces appearing in byzantine icons, In Journal of Cultural Heritage, 4 (13), 404-412.

Pallas, J \& Economides, A.A. (2008). Evaluation of art museums' web sites worldwide. In Information Services and Use, 1 (28), 45-57.

Pallud, J. \& Straub, D.W. (2014). Effective website design for experience-influenced environments: The case of high culture museums, In Information \& Management, 3 (51), 359-373.

Pikov, N. (2015). Touching an ancient stone: $3 \mathrm{~d}$ modeling and augmented reality techniques for a collection of petroglyphs from State Hermitage Museum, In IEEE, 739-740.

Rumyantsev, M.V., Baryshev, R.A. \& Genvald (2010). Web-predstavitel'stvo regional'nogo muzeiia [Web representation of the regional museum], In Prikladnaia informatika [Applied Computer Science], 5 (29), 70-77.

Rumyantsev, M.V., Smolin, A.A., Baryshev, R.A., Rudov, I.N. \& Pilov, N.O. (2011). Virtual'naia rekonstruktsiia ob'ektov istoriko-kul'turnogo naslediia [Virtual recontruction of the sites of histroical and cultural heritage], In Prikladnaia informatika [Applied Computer Science], 6 (36), 62-77.

Rumyantsev, M.V. \& Aminova, G.U. (2008). Krasnoyarskii opyt integratsii informatsionnykh tekhnologii i gumanitarnogo znaniia (o realizatsii spetsial'nosti “prikladnaia informatika v muzeinykh i vystavochnykh kompleksakh" v SFU) [Krasnoyarsk experience in the integration of information 
technology and the humanities (on the implementation of the course "Applied computer science in museums and exhibition centres" at SibFU), In Informatsionnyi biulleten assotsiatsii Istoriia $i$ komp'iuter [Information Bulletin of the Association "History and Computer"], 35, 225-227.

Sylaiou, S., Mania, K., Karoulis, A. \& White, M. (2010). Exploring the relationship between presence and enjoyment in a virtual museum, In International Journal of Human-Computer Studies, 5 (68), 243-253.

Trinchão Andrade, B., Mazetto Mendes, C., De Oliveira Santos, J., Pereira Bellon, O.R. \& Silva, L. (2012). 3D preserving xviii century barroque masterpiece: Challenges and results on the digital preservation of Aleijadinho's sculpture of the Prophet Joel, In Journal of Cultural Heritage, 2 (13), 210-214.

Voloshchuk, A.V. Digitalizatsiia muzeinykh kollektsii [Digitalization of museum collections]. Molodezh i nauka: sbornik materialov IX Vserossiiskoi nauchno-tekhnicheskoi konferentsii studentov, aspirantov i molodykh uchenykh s mezhdunarodnym uchastiem, posviashchennoi 385-letiiu so dnia osnovaniia g. Krasnoiarska [Youth and Science: Collection of articles of the $9^{\text {th }}$ All-Russian research and technology conference of students, postgraduate students and young researchers with international participation devoted to the $385^{\text {th }}$ anniversary since foundation of Krasnoyarsk city. Available at: http:// conf.sfu-kras.ru/sites/mn2013/section040.html.

Zaitseva, O.V. (2014). 3d revoliutsiia $\mathrm{v}$ arkheologicheskoi fiksatsii $\mathrm{v}$ rossiiskoi perspektive [Perspectives of 3D revolution in archeological recording in Russia], In Sibirskie istoricheskie issledovaniia [Siberian Historical Research], 4, 10-20.

\section{Проектная деятельность кафедры цифровых гуманитарных наук и современные тенденции развития информационных технологий}

М.В. Румянцев, И.Н. Рудов

Сибирский федеральный университет Россия, 660041, Красноярск, пр. Свободный, 79

Настоящая статья посвящена представлению результатов проектной деятельности кафедры информационных технологий в креативных и культурных индустриях Гуманитарного института Сибирского федерального университета в аспекте изменений информационных технологий.

Ключевые слова: дополненная реальность, 3d-моделирование, виртуальная реконструкиия, музей, дигитализация, оцифровка, историко-культурное наследие, проектный менеджмент.

Научная специальность: 24.00.00 - культурология. 